\title{
Fate of metallic engineered nanomaterials in constructed wetlands: prospection and future research perspectives
}

(1)

\author{
Hannele Auvinen ${ }^{\mathrm{a}, b^{*}}$, Vincent Gagnon ${ }^{\mathrm{c}}$, Diederik P.L. Rousseau ${ }^{\mathrm{a}}$, Gijs Du Laing ${ }^{\mathrm{b}}$
}

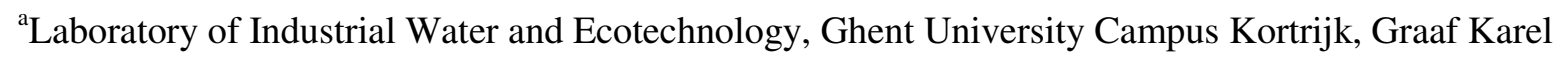

De Goedelaan 5, Kortrijk, 8500, Belgium (hannele.auvinen@ugent.be; diederik.rousseau@ugent.be)

${ }^{\mathrm{b}}$ Laboratory of Analytical Chemistry and Applied Ecochemistry, Ghent University, Coupure Links

653, Ghent, 9000, Belgium (gijs.dulaing@ugent.be)

${ }^{\mathrm{c}}$ Environmental Sciences Group, Department of Chemistry and Chemical Engineering, Royal Military

College of Canada, 13 General Crerar Crescent, Kingston, Ontario, K7K 7B4, Canada

(vincent.gagnon@rmc.ca)

* Corresponding author: Hannele.Auvinen@UGent.be

\section{Abstract}

Metallic engineered nanomaterials (ENMs) undergo various transformations in the environment which affect their fate, toxicity and bioavailability. Although constructed wetlands (CWs) are applied as treatment systems for waste streams potentially containing metallic engineered nanomaterials (ENMs), little is known about the fate and effects of ENMs in CWs. Hence, literature data from related fields such as activated sludge wastewater treatment and natural wetlands is used to predict the fate and effects of ENMs in CWs and to analyze the risk of nanomaterials being released from CWs into surface waters. The ENMs are likely to reach the $\mathrm{CW}$ (partly) transformed and the transformations will continue in the $\mathrm{CW}$. The main transformation processes depend on the type of ENM and the ambient environmental conditions in the CW. In general, ENMs are expected to undergo sorption onto (suspended) organic matter and plant roots. Although the risk of ENMs being released at high concentrations from CWs is estimated low, caution is warranted because of the estimated rise in the production of these materials. As discharge of (transformed) ENMs from CWs during normal operation is predicted to be low, future research should rather focus on the effects of system malfunctions (e.g. short-circuiting). Efficient retention in the $\mathrm{CW}$ and increasing production volumes 
in the future entail increasing concentrations within the $\mathrm{CW}$ substrate and further research needs to address possible adverse effects caused.

\section{Key words}

Nanoparticle, transformation, wastewater, effluent, discharge, TSS

\section{Introduction}

The growing production and widespread use of engineered nanomaterials (ENMs) in commercial products leads to increasing presence of these materials in the environment. The ENMs are defined by their small particle size $(<100 \mathrm{~nm})$ and large specific surface area which can increase their mobility, bioavailability and reactivity in comparison to their bulk counterparts (Christian et al. 2008; Navarro et al. 2008). Due to these characteristics ENMs pose a potential risk to the environment.

In principle, European environmental legislation for water, waste and air covers also ENMs and hence, this legislation would theoretically allow limiting the presence of ENMs in environmental media (Ganzleben et al. 2011). However in practice, this is difficult for several reasons. Firstly, suitable analysis methods are lacking to allow measuring low concentrations of ENMs in environmental samples and distinguishing between naturally occurring nano-scale particles from engineered nanomaterials. Secondly, due to the lacking analysis methodologies, there is no monitoring data of the presence of ENMs in surface waters nor is there enough evidence on ENM causing imminent risk in surface waters. Hence, ENMs cannot be listed as priority substances in the Water Framework Directive which would entail their monitoring in surface water and allow setting environmental quality standards. As a consequence, the measures to avoid potential emissions to the environment limit to risk management measures given in REACH. Through REACH companies are required to register the chemical substances, including ENMs, used in the products and provide risk management measures to the users (ECHA 2012).

ENMs can be discharged to the aquatic environment via the production, usage and disposal phases (Figure 1). For example, silver nanoparticles (Ag-NPs) and titanium dioxide nanoparticles $\left(\mathrm{TiO}_{2}-\mathrm{NPs}\right)$ 
are used in common household products. As they are used in textiles, plastics and cosmetics, they can be released from the product during washing and end up in wastewater (e.g. Benn \& Westerhoff 2008). Also, ENMs can be released from (weathered) materials, e.g. from painted facades during rainfall and then be transported with runoff (Kaegi et al. 2008). A large amount of ENM containing materials are disposed of in landfills (Keller and Lazareva 2013) and leaching could occur (Gottschalk and Nowack 2011).

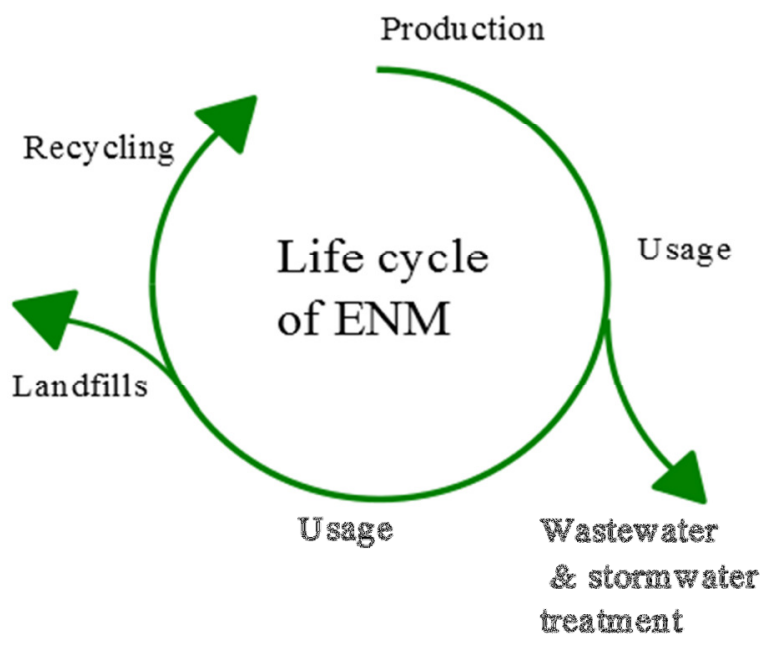

Figure 1: Possible release of ENM to the environment during their life cycle

A typical constructed wetland $(\mathrm{CW})$ for wastewater treatment is a sub-surface flow $\mathrm{CW}$, where water flows either vertically or horizontally through a gravel or sand bed. CWs are planted to increase the microbial activity in the bed, to increase nutrient removal and for aesthetic reasons. CWs are commonly used as decentralized wastewater treatment in rural areas because of, on one hand their robust treatment and low maintenance requirement and, on the other hand, because of their large land area requirement, which does restrict their use in urban areas. In addition to domestic wastewater, also industrial wastewater, stormwater and landfill leachate, i.e. potentially ENM bearing waste streams, are treated in CWs (Kadlec and Wallace 2009). When used for the treatment of domestic wastewater, CWs are most often used as a secondary treatment for settled wastewater but in some cases also as tertiary treatment after activated sludge treatment or rotating biological contactor. In France, constructed wetlands are often designed to treat domestic wastewater without primary settling (Molle et al. 2005). This creates a sludge layer on top of the wetland, which is disposed of about every 10 
years. Although CWs constitute a possible source of ENMs in the environment, there is little data available in literature on the fate and removal efficiency of ENMs in CWs.

In this review, we provide an overview of transformation processes of ENMs and environmental factors affecting these processes based on literature data, and discuss the probable fate of ENMs in CWs. We also discuss the likelihood of ENMs being released from CWs and assess the potential toxicity of ENMs on the wastewater treatment processes occurring in CWs.

\section{Predicted environmental concentrations of ENMs}

At the moment, little is known about the environmental concentrations of ENMs because current analytical methodologies do not allow distinguishing between naturally occurring nanoscale materials and ENMs (von der Kammer et al. 2012). However, several calculations of predicted environmental concentrations (PEC) based on a probabilistic material flow analysis from a life-cycle perspective of ENM containing products have been performed. Blaser et al. (2008) estimated that the concentration of Ag-NPs in wastewater influent ranges between 2 to $18 \mu \mathrm{g} / \mathrm{L}$ which is somewhat higher than measured for nanosized $\mathrm{Ag}$ in real wastewater influent ( $<1.5 \mu \mathrm{g} / \mathrm{L}$; Li et al. 2013). Li et al. (2013) also showed that the concentration of the nanosized $\mathrm{Ag}$ decrease considerably during wastewater treatment, to $<12 \mathrm{ng} / \mathrm{L}$. This is in agreement with modeling studies: predicted concentrations of 0.06$16 \mathrm{ng} / \mathrm{L}, 13-110 \mu \mathrm{g} / \mathrm{L}$ and $0.05-0.29 \mu \mathrm{g} / \mathrm{L}$ for Ag-NPs, $\mathrm{TiO}_{2}$-NPs and zinc oxide NPs (ZnO-NPs) in wastewater effluent, respectively. The concentrations of ENMs decrease further upon discharge to surface water due to dilution. The concentrations of $\mathrm{Ag}-\mathrm{NPs}$, $\mathrm{TiO}_{2}-\mathrm{NPs}$ and $\mathrm{ZnO}-\mathrm{NPs}$ in European surface water were estimated to be very low, on average $0.66 \mathrm{ng} / \mathrm{L}, 0.53 \mu \mathrm{g} / \mathrm{L}$ and $0.09 \mu \mathrm{g} / \mathrm{L}$, respectively (Sun et al. 2014). Furthermore, Markus et al. (2013) predicted that the contribution of Ag-NPs, $\mathrm{TiO}_{2}$-NPs and $\mathrm{ZnO}-\mathrm{NPs}$ to the current total load of these metals in the rivers Rhine and Meuse is insignificant. The ENMs which are removed during wastewater treatment in the $\mathrm{CW}$ are retained within the substrate possibly bringing the biofilm into contact with a growing concentration of ENMs over time (see further section 3.4). 
The growing production and accumulation of ENMs in the CW substrate could thus cause toxic concentrations to appear in the long term. It must be noted however, that the concentration of the corresponding bulk metals is currently expected to be much higher than that of the nanoparticles. Lesage et al. (2007) who studied the accumulation of heavy metals in a horizontal sub-surface flow $\mathrm{CW}$ treating domestic wastewater reported average influent concentrations of $20 \mu \mathrm{g} \mathrm{Cu} / \mathrm{L}, 120 \mu \mathrm{g}$ $\mathrm{Zn} / \mathrm{L}$ and $550 \mu \mathrm{g} \mathrm{Fe} / \mathrm{L}$, for example. Hence, the estimated concentration of $\mathrm{ZnO}-\mathrm{NPs}$ in the influent is more than 100 times lower than that of its bulk counterpart. In case of Ag, Ag-NPs released from plastics and textiles can form a large fraction of the total Ag load in the influent if industrial wastewater is not treated in the $\mathrm{CW}$.

\section{Possible transformation processes affecting the fate of ENMs in constructed wetlands}

When ENMs are released to the aquatic medium they can undergo physical, chemical and biological transformations which affect their fate and behavior in the environment. These transformations include primarily processes such as dissolution, aggregation, sedimentation, sorption onto particulate matter and other solid surfaces and interaction with dissolved ions. The transformation processes are dependent on both the properties of the ENM (e.g. type, coating, size) and the prevailing environmental conditions (e.g. $\mathrm{pH}$, presence of ions, natural organic matter and dissolved oxygen). In the following sections, the main transformation processes of different ENMs reported in earlier literature are reviewed and the environmental factors affecting these processes are discussed in relation to their possible fate in CWs.

\subsection{Aggregation and sedimentation}

Aggregation and subsequent sedimentation of ENMs decrease their mobility and bioavailability by restricting their distribution in the aquatic environment. Also, the surface area of the particles decreases due to aggregation which in turn decreases its reactivity, affecting the release of ions for instance (see further section 3.2).

Nanosized dispersed particles are not likely to settle. They move about in the dispersion by Brownian motion and along the streaming water. When this movement brings particle surfaces in contact, 
thermodynamic interactions allow aggregation to occur (Zhang 2014). ENMs can undergo two forms

124 of aggregation in the environment, homo- and heteroaggregation (Figure 2). Whereas in

125 homoaggregation particles of the same type collide and form aggregates, in heteroaggregation ENM

126 aggregates with another kind of particulate or colloidal matter (Quik et al. 2014). When ENMs are

127 scarcely present, as in most environmental media, the likelihood of homoaggregation is low (Hotze et

128 al. 2010). In wastewater, for example, heterogenic particulate matter is ubiquitous and hence,

129 aggregates formed with this matter and ENMs are much more likely to be formed than aggregates

130 composed of only ENMs.
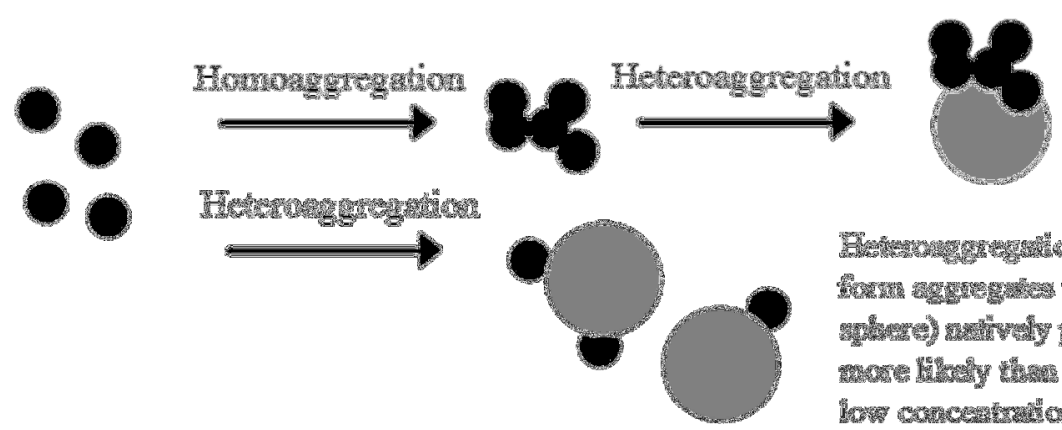

Dhs: Thx

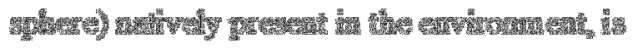

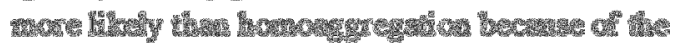

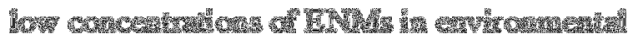

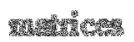

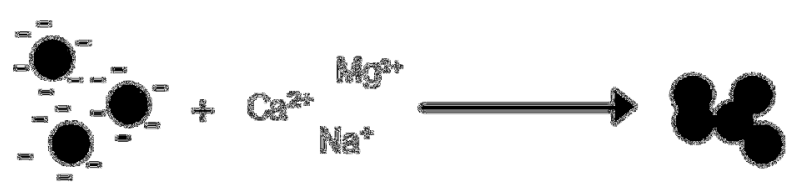

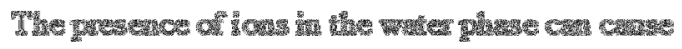

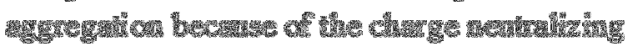

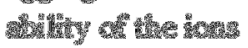

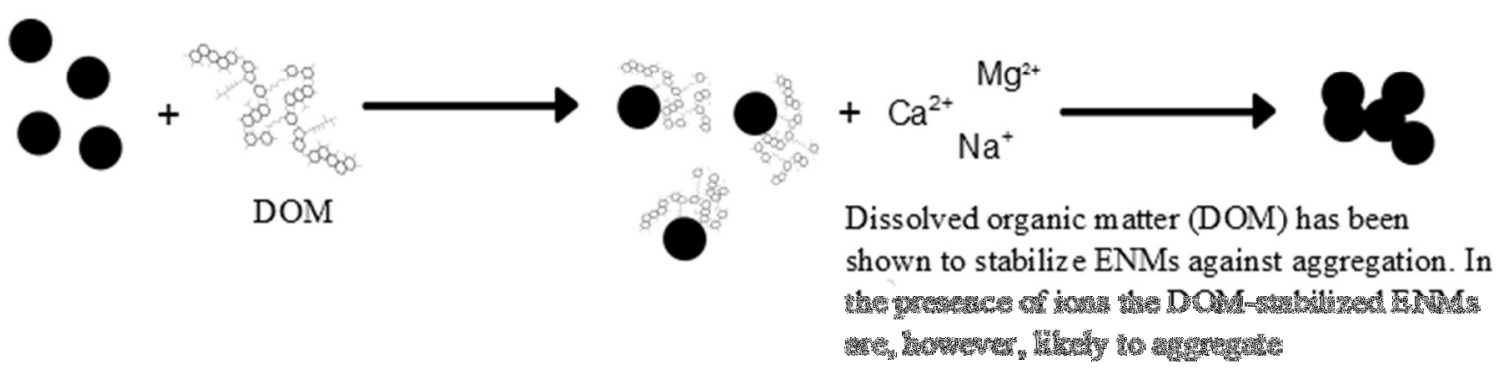

Figure 2 - Aggregation of ENMs in environmental matrices

133 Because the properties of ENMs are related to their small size and surface properties, the ENMs are 134 mostly coated to enhance their dispersion stability, i.e. to prevent aggregation (Hotze et al. 2010). The 135 mechanism of stabilization, electrostatic or steric, can have an impact on the behavior of the ENM in 136 the environment (Christian et al. 2008). Electrostatically stabilized ENMs are kept in dispersion 137 through the repulsion of similar surface charges and are thus more susceptible to changes in ionic 
concentrations in the media than sterically stabilized particles having an isolating polymer coating to

139 keep them in dispersion. Several studies have investigated the effect of ionic strength on the 140 aggregation behavior of different types of ENMs. Huynh \& Chen (2011) and Li et al. (2010) studied the effects of $\mathrm{NaCl}, \mathrm{MgCl}_{2}$ and $\mathrm{CaCl}_{2}$ on $\mathrm{Ag}-\mathrm{NPs}$ with different coatings. The common conclusion that can be drawn from these studies is that the type of ion is more determinant of the aggregation than the mechanism of stabilization (Figure 2). For example, complete aggregation of citrate-coated (i.e.

144 electrostatic stabilization) or polyvinylpyrrolidone (PVP)-coated (i.e. steric stabilization) Ag-NPs is achieved by $>10 \mathrm{mM}$ of monovalent ions, while only $>1 \mathrm{mM}$ of divalent ions is needed for complete aggregation. Divalent ions, such as e.g. $\mathrm{Ca}^{2+}$, have a stronger charge neutralizing ability than monovalent ions, e.g. $\mathrm{Na}^{+}$(El Badawy et al. 2012). Also $\mathrm{TiO}_{2}-\mathrm{NPs}$, cerium dioxide $\mathrm{NPs}\left(\mathrm{CeO}_{2}-\mathrm{NPs}\right)$, 148 copper oxide nanoparticles (CuO-NPs), copper nanoparticles (Cu-NPs) and ZnO-NPs have been 149 observed to undergo aggregation and sedimentation at elevated ionic strength (Zhang et al. 2009; Zhou 150 and Keller 2010; Gallego-Urrea et al. 2014). Although the natural concentrations of the ions are somewhat lower (in the range of $0.5-5 \mathrm{mM}$; Verbanck et al. 1989) than in the studies on synthetic waters, a cumulative effect can be expected in real freshwater and wastewater samples.

Similarly to coating, natural dissolved organic matter (DOM) which attaches on the surface of the ENMs has a stabilizing effect on the ENMs due to which the ENMs are more persistent to aggregation (Gallego-Urrea et al. 2014) (Figure 2). DOM has been shown to cause disaggregation and subsequent decrease in Ag-NP size distribution at concentrations $5-20 \mathrm{mg} / \mathrm{L}$ total organic carbon (TOC) as Suwannee river humic acid (SRHA) and up to $15 \mathrm{mg} \mathrm{Ag/L} \mathrm{(Fabrega} \mathrm{et} \mathrm{al.} \mathrm{2009;} \mathrm{Kanel} \mathrm{et} \mathrm{al.} \mathrm{2015;}$

158 Metreveli et al. 2015). Similarly, the presence of DOM has been shown to have a stabilizing effect on $159 \mathrm{TiO}_{2}$-NPs (Zhang et al. 2009), $\mathrm{CeO}_{2}$-NPs (Van Hoecke et al. 2011), CuO-NPs (Ben-Moshe et al. 160 2010), ZnO-NPs (Zhang et al. 2009), iron trioxide NPs $\left(\mathrm{Fe}_{2} \mathrm{O}_{3}\right)$ (Zhang et al. 2009; Ben-Moshe et al. 161 2010), gold NPs (Au-NPs) (Stankus et al. 2011) and nickel oxide NPs (NiO-NPs) (Zhang et al. 2009). 162 However, there are also contradictory results showing no significant impact of SRHA (2.5 - $10 \mathrm{mg}$ TOC/L) on the aggregation state of carbonate-coated Ag-NPs or disaggregation of pre-agglomerated Ag-NPs (Piccapietra et al. 2012). 
The dissolved fraction of the total natural organic carbon is some $20-30 \%$ in wastewater influent but in effluent nearly $100 \%$ (Dignac et al. 2000). Studies on dissolved organic carbon (DOC) removal in activated sludge treatment plants have reported concentrations of $10-20 \mathrm{mg} \mathrm{DOC} / \mathrm{L}$ in wastewater effluent (Dignac et al. 2000; Katsoyiannis and Samara 2007) proving the relevance of the above mentioned studies in the context of wastewater treatment. In CWs similar removal of the particulate fraction is expected due to efficient removal of total suspended solids (TSS) (Vymazal 2009) but the composition and concentration of DOM may differ from that in an activated sludge treatment system. A study of Barber et al. (2001) on tertiary surface-flow CWs treating domestic wastewater, pulp mill and dairy effluent showed that CWs receiving treated wastewater can even produce an increase in DOC. The autochthonous DOM in CWs originates primarily from microbial activity (Quanrud et al. 2004), plant debris (Pinney et al. 2000) and plant root exudates (Glatzel et al. 2003). This indicates that the DOM discharged from CWs differs probably greatly from that of activated sludge treatment systems and may have a different impact on the stability of ENMs. However, in wastewater the ionic strength, especially the presence of $\mathrm{Ca}^{2+}$, is probably more determinant of aggregation than DOM. Metreveli et al. (2015) showed that above a relatively low concentration of $\mathrm{Ca}^{2+}(\sim 20 \mathrm{mg} / \mathrm{L}$; moderately soft water) Ag-NPs aggregated until sedimentation independently of the presence or absence of SRHA.

\subsection{Dissolution}

When an ENM is dissolved, metal ions are released from its surface. The dissolution process of ENMs has environmental relevance from the risk analysis perspective because ions are often more toxic than ENMs (Sotiriou and Pratsinis 2010; Li et al. 2011; Levard et al. 2013a; Moore et al. 2016). However, dissolution can possibly reduce the mobility as $\mathrm{Ag}^{+}$and $\mathrm{Ce}^{2+}$ appear to be more efficiently bound to soil/sediment than their nanoparticle counterparts (Cornelis et al. 2012; Van Koetsem et al. 2015).

Odzak et al. (2014) compared the dissolution tendencies of four different types of ENMs in artificial aqueous media chemically similar to environmental waters, and found clear differences in the dissolution rates of the ENMs. While Ag-NPs citrate, gelatin, PVP and chitosan coated Ag-NPs were very poorly soluble (only some \%), ZnO-NPs were very rapidly largely dissolved. The dissolution of 
CuO-NPs was found to be incomplete and faster than that of carbon-coated $\mathrm{Cu}-\mathrm{NPs}$ but both dissolved to a smaller extent than ZnO-NPs. Quik et al. (2014) studied the environmental transformations of $\mathrm{CeO}_{2}$-NPs in different surface waters and observed only minor dissolution $(<0.4 \%)$.

The dissolution rate is also related to particle size; small ENMs being dissolved faster than larger ones due to their greater surface-to-volume ratio and subsequent increased reactivity (Zhang et al. 2011). As a consequence, the dissolution rate of aggregated ENMs is reduced (Li and Lenhart 2012).

Odzak et al. (2014) observed that the dissolution tendency is to some extent also dependent on the coating of the ENM. The coating stabilizes the ENM against dissolution by isolating the metal core inside the coating (as was discussed in section 3.1). The presence of NOM in the water also inhibits the dissolution of ENMs and this is a dose dependent manner (Liu and Hurt 2010). The inhibition is likely caused by NOM attaching onto the surface of the ENM which results in steric stabilization analogue to a coating (Delay et al. 2011).

Ions dissolved in the water can affect the dissolution rate of ENMs. The reaction with sulfide, sulfidation, can either decrease or increase the dissolution process (Levard et al. 2011; Ma et al. 2013; Ma et al. 2014), as is also discussed in section 3.3. ZnO-NPs can react with phosphates to form precipitates which have lower solubility than the ZnO-NPs themselves (Rathnayake et al. 2014). The reaction between $\mathrm{Ag}-\mathrm{NPs}$ and chloride ions can decrease the release of $\mathrm{Ag}^{+}$by formation of a solid $\mathrm{AgCl}$ precipitate on the outer layer of the $\mathrm{ENM}$ ( $\mathrm{Li}$ et al. 2010) if the molar $\mathrm{Cl} / \mathrm{Ag}$ ratio is $\leq 535$ ) (Levard et al. 2013b). However, at environmentally relevant (low) concentrations of Ag-NPs (see section 2) in wastewater the $\mathrm{Cl} / \mathrm{Ag}$ molar ratio is much higher (in the range of $10^{5}$ if $1 \mu \mathrm{g} \mathrm{Ag} / \mathrm{L}$ and $100 \mathrm{mg} \mathrm{Cl} / \mathrm{L}$ is assumed) and this promotes the formation of readily soluble $\mathrm{Ag}-\mathrm{Cl}$ complexes instead (Levard et al. 2013b).

Ag-NPs are more easily dissolved if there is oxygen present in the environment because oxygen causes the Ag-NPs to oxidize to silver oxides $\left(\mathrm{Ag}_{2} \mathrm{O}\right)$ which easily dissolve upon contact with water (Levard et al. 2012). In CWs the dissolved oxygen concentration depends on the type (vertical subsurface (VSSF) or horizontal sub-surface flow (HSSF)) and possible application of active aeration. Higher dissolved oxygen concentrations are usually measured in VSSF CWs than in HSSF CWs 
because the batch feeding mode applied in VF CWs allows the pores to be filled with air between feeding events.

\subsection{Sulfidation}

The reaction of ENMs with sulfides is interesting because sulfidation of Ag-NPs has been shown to decrease their toxicity (Reinsch et al. 2012; Levard et al. 2013a). When sulfide concentration is low, e.g. in surface water, sulfidation of Ag-NPs occurs via oxidative dissolution and subsequent precipitation (Liu et al. 2011) (Figure 3). First, $\mathrm{Ag}^{+}$is formed via oxidative dissolution in the presence of dissolved oxygen, after which these ions precipitate with sulfides to form silver sulfide $\left(\mathrm{Ag}_{2} \mathrm{~S}\right)$. For the reaction to occur, sulfide can be either free or in the form of metal sulfides (e.g. CuS, $\mathrm{ZnS}$ ) (Thalmann et al. 2014). When sulfide concentration is high, e.g. within HSSF CWs, sulfidation of AgNPs occurs via a direct particle-fluid reaction where the $\mathrm{Ag}$ phase is converted to $\mathrm{Ag}_{2} \mathrm{~S}$ phase (Liu et 2009).

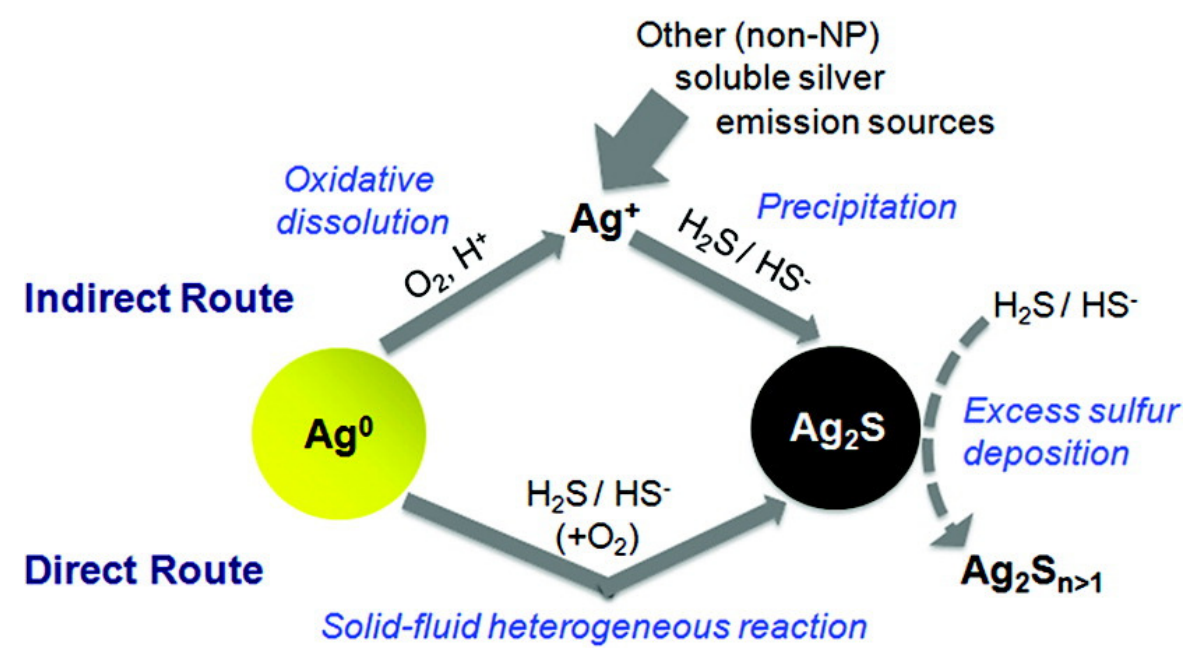

Figure 3 - Sulfidation pathways of Ag-NPs. Reprinted with permission from Liu et al. (2011):

Kinetics and mechanisms of nanosilver oxysulfidation. Environmental Science and Technology 45 (17), $7345-7353$. Copyright 2017 American Chemical Society.

237 Ma et al. (2013) studied the sulfidation mechanism of ZnO-NPs in the laboratory. While a solid $\operatorname{Ag}_{2} \mathrm{~S}$ 238 phase is formed during the sulfidation of $\mathrm{Ag}-\mathrm{NPs}$, the $\mathrm{ZnO}$ core becomes covered by nanocrystalline zinc sulfide $(\mathrm{ZnS})$. The $\mathrm{ZnS}$ shell does not quench the leaching of $\mathrm{Zn}^{2+}$ as efficiently as the $\mathrm{Ag}_{2} \mathrm{~S}$ phase 240 (Levard et al. 2011). In contrast to Ag-and ZnO-NPs, the sulfides formed of CuO-NPs are more prone 
to dissolution than the original NP (Ma et al. 2014). The main reason is proposed to be the formation of poorly ordered easily soluble $\mathrm{Cu}_{\mathrm{x}} \mathrm{S}_{\mathrm{y}}$ phases instead of poorly soluble $\mathrm{CuS}$. The reaction occurs through both dissolution and reaction with sulfide as well as a direct solid-fluid sulfidation.

Sulfidation has been identified as one of the primary transformation mechanisms of Ag-NPs in the sewer systems (Kaegi et al. 2013) as well as in pilot- and full-scale activated sludge treatment systems (Kaegi et al. 2013; Kent et al. 2014) and in terrestrial and freshwater wetland mesocosms (Lowry et al. 2012a; Moore et al. 2016). Lombi et al. (2013) showed that Ag-NPs were sulfidized also in laboratoryscale anaerobic digestors fed with real sludge and wastewater and that the reaction occurred irrespective of surface functionalities or core composition $(\mathrm{Ag}$ or $\mathrm{AgCl})$ of the NP. Lowry et al. (2012a) noticed however that sulfidation in the freshwater wetland mesocosms was slower than expected based on laboratory studies and that the sulfidation had occurred only partially after 18 months and leaching of $\mathrm{Ag}^{+}$was still possible. Once fully sulfidized, $\mathrm{Ag}_{2} \mathrm{~S}$ is very stable as it does not oxidize during prolonged aeration (Choi et al. 2009) and remains stable in wastewater sludge over more than 50 years (Donner et al. 2015).

ZnO-NPs are also prone to sulfidation but they may not be equally persistent as sulfidized Ag-NPs. In short-term, the sulfidation of ZnO-NPs seems to be efficient as Brunetti et al. (2015) showed that the spiked ZnO-NPs nearly completely sulfidized in a full-scale sewer experiment. Lombi et al. (2012) studied the fate of ZnO-NPs during anaerobic digestion of sewage sludge and in conditions simulating the post-processing of digested sludge in composting/stockpiling. First, the ZnO-NPs underwent sulfidation which represented $67-96 \%$ of the total Zn. The Zn speciation was affected by the long (two months) incubation simulating composting/stockpiling and during this phase, $\mathrm{ZnS}$ was oxidized and $\mathrm{Zn}$ became associated with iron precipitates and complexed by phosphates.

The sulfide concentration of the wastewater (in sewer $\sim 4 \mathrm{mg} \mathrm{S} / \mathrm{L}$; Kaegi et al. 2013) is expected to increase in CWs due to microbial sulfate reduction, where sulfate-reducing bacteria catalyze the production of sulfide from sulfate in the absence of dissolved oxygen (Wu et al. 2013). If we assume the sulfate removal efficiency to be $\sim 30 \%$ (based to laboratory-scale experiments of Wiessner et al. 
al. 1987), an increase of $\sim 9 \mathrm{mg} \mathrm{S} / \mathrm{L}$ can be expected in CWs. Bearing in mind the low predicted environmental concentrations of ENMs (see section 2), the S:Ag and S:ZnO molar ratio's would be in the range of $10^{4}$. Since the molar ratios necessary for the sulfidation of Ag-NPs and ZnO-NPs is much lower (in the range of $0.5-1$; Levard et al. 2011), (partial) sulfidation of these ENMs in CWs seems unavoidable.

\subsection{Adsorption}

In general, adsorption of molecules onto surfaces can result from three types of interactions, physical, chemical and electrostatic interactions (Voice and Weber 1983). In the environment, these interactions are usually involved in the sorption process simultaneously at varying degrees because of the heterogeneous chemical structure of natural (suspended) solids. In case of ENMs, their surface properties, such as surface charge and hydrophobicity/hydrophilicity, are likely to affect the adsorption efficiency (Lin et al. 2010). Hence, the coating of the ENM plays an important role in defining its sorption tendency. Song et al. (2011) investigated the effects of organic coatings of different hydrophobicity on Ag-NP adsorption onto chemically heterogeneous collector surfaces. The study indicated that ENM coatings with higher hydrophobicity (PVP and gum arabic (GA)) had greater attachment to hydrophobic surfaces than particles with a less hydrophobic coating (citrate). However, it is crucial to note that the surface properties of ENMs are affected by molecules present in the environmental matrix and hence, to predict the adsorption tendency of the ENMs based on their pristine structure is not possible. As discussed before, in the environment the ENMs are subjected to interactions with ions (e.g. sulfides, phosphates) and macromolecules (e.g. humic acids, proteins) which are likely to result in modifications in the (surface) structure and charge of the ENMs and hence, affect their fate in the environment (Lin et al. 2010; Lowry et al. 2012b).

ENMs are, in general, shown to attach efficiently to soil and sediment, especially to the organic fraction present (Cleveland et al. 2012; Coutris et al. 2012), although $\mathrm{Ag}-\mathrm{NPs}$ and $\mathrm{CeO}_{2}-\mathrm{NPs}$ have

292 been shown to be less prone to adsorption than their ions, indicating that these ENMs have a higher mobility than their ions (Cornelis et al. 2012; Van Koetsem et al. 2015). In wastewater treatment, the 
partition to great extent to organic matter, support the hypothesis that organic matter, when suspended, is likely to be a major transport medium for ENMs. Thus, enhancing the removal of TSS during wastewater treatment is likely to result in improved removal of ENMs (Kaegi et al. 2013).

The removal of TSS is mostly very efficient in CWs. The long-term monitoring of 10 Czech HSSF

CWs treating domestic wastewater showed that the CWs reliably decreased the TSS concentration to mostly under $20 \mathrm{mg} / \mathrm{L}$ independent of the influent concentration (maximum reported concentration $1457 \mathrm{mg} / \mathrm{L}$ ) (Vymazal 2011). During the life time of the CW, solids are building up within the substrate, especially at the inlet of the CW. Although the fraction of organic matter in these solids can vary greatly (5-82\%; Caselles-Osorio et al. 2007) since it is dependent on the type of wastewater and loading rate, these solids can form a sink for ENMs. The sludge layer on top of the French type VSSF CWs can function similarly reducing the amount of ENMs reaching the actual CW substrate. The surface of the substrate is inhabited by micro-organisms which form a biofilm. Extracellular polymeric substance (EPS) present in the biofilm efficiently adsorbs ENMs (Puay et al. 2015). In mature CWs plant roots form a large surface area which likely serves as a binding site for ENMs

309 (Jacob et al. 2013), possibly (at least partly) due to biofilm formation on top of the root surface. In

310 addition, metal retention in the roots can improve if iron plaque is formed on the roots (Jiang et al.

311 2009). This iron precipitate is caused by oxidation of ferrous iron in anoxic conditions (Jiang et al.

312 2009), e.g. upon exposure to wastewater from metallurgical industry or landfill leachate. 


\begin{tabular}{|c|c|c|c|c|c|}
\hline $\begin{array}{l}\text { Type of } \\
\text { ENM }\end{array}$ & Process description & Coating & $\begin{array}{c}\text { Retention } \\
(\%)\end{array}$ & Observations & Reference \\
\hline \multirow[t]{5}{*}{ Ag } & $\begin{array}{l}\text { Pilot-scale WWTP consisting of non-aerated } \\
\text { tank, aerated tank and settler; average sludge } \\
\text { age of } 14 \text { days }\end{array}$ & $\begin{array}{l}\text { Polyoxyethylene fatty } \\
\text { acid ester }\end{array}$ & 85 & $\begin{array}{l}\text { Mass balance suggests that } \sim 5 \% \text { of Ag left } \\
\text { the WWTP with the effluent }\end{array}$ & $\begin{array}{l}\text { Kaegi et al. } \\
2011\end{array}$ \\
\hline & $\begin{array}{l}\text { Batch-tests on activated sludge; contact time } \\
24 \mathrm{~h}\end{array}$ & Citrate, PVP & $\sim 99$ & & $\begin{array}{l}\text { Kaegi et al. } \\
\quad 2013\end{array}$ \\
\hline & $\begin{array}{l}\text { Batch-tests on activated sludge; contact time } 3 \\
\mathrm{~h}\end{array}$ & Carboxyl & 39 & & $\begin{array}{l}\text { Kiser et al. } \\
\quad 2010\end{array}$ \\
\hline & & None & 97 & & \\
\hline & $\begin{array}{l}\text { Simulated WWTP with primary settler, and } \\
\text { SBR }\end{array}$ & Citrate & 100 & $\begin{array}{l}>90 \% \text { of Ag-NPs remained in the water } \\
\text { stream after primary clarification; complete } \\
\text { removal after aeration and secondary } \\
\text { clarification }\end{array}$ & $\begin{array}{l}\text { Hou et al. } \\
\quad 2012\end{array}$ \\
\hline $\mathrm{TiO}_{2}$ & $\begin{array}{l}\text { Batch-tests on activated sludge; contact time } 3 \\
\text { h }\end{array}$ & None & 23 & & $\begin{array}{l}\text { Kiser et al. } \\
2010\end{array}$ \\
\hline $\mathrm{CeO}_{2}$ & $\begin{array}{l}\text { Model WWTP with aeration tank and settler; } \\
\text { sludge age not reported }\end{array}$ & None/surfactant & $>94$ & & $\begin{array}{l}\text { Limbach et } \\
\text { al. } 2008\end{array}$ \\
\hline $\mathbf{C u}$ & $\begin{array}{l}\text { Batch-tests on activated sludge (filtrates); } \\
\text { contact time } 20 \mathrm{~h}\end{array}$ & N/A & $\sim 95$ & $\begin{array}{l}\text { Mainly removed by aggregation and settling } \\
\text { rather than biosorption. }\end{array}$ & $\begin{array}{l}\text { Ganesh et al. } \\
\quad 2010\end{array}$ \\
\hline $\mathrm{ZnO}$ & $\begin{array}{l}\text { Simulated WWTP with primary settler and } \\
\text { SBR. }\end{array}$ & None & 100 & $\begin{array}{l}\text { Simulated primary settler removed } \sim 70 \% \text { of } \\
\text { ZnO-NPs. Further removal in SBR. }\end{array}$ & $\begin{array}{l}\text { Hou et al. } \\
2013\end{array}$ \\
\hline $\mathbf{A u}$ & $\begin{array}{l}\text { Batch-tests on activated sludge; contact time } \\
24 \mathrm{~h}\end{array}$ & & $\sim 99$ & & $\begin{array}{l}\text { Kaegi et al. } \\
2013\end{array}$ \\
\hline
\end{tabular}


316 Some plant species are known to be able to take up metals and when the metals are principally accumulated in the aboveground biomass at high concentrations, one speaks of hyperaccumulators (for review see Krämer 2010). There is no one species which can accumulate different metals at equal amounts (Weiss et al. 2006). Generally, only free metal ions, soluble metal complexes and metal ions occupying exchangeable sites or attached on inorganic soil constituents are bioavailable for plants (Salt et al. 1995). Metals existing in the environment bound to organics, as precipitates or in the silicate mineral structure (indigenously present) are, in general, not bioavailable for plants. ENMs have been shown to be bioavailable to plants to some extent (Figure 4). Their bioavailability to plants is restricted by their size as particles up to only about $5 \mathrm{~nm}$ in diameter can traverse an undamaged cell wall efficiently (Dietz and Herth 2011). Also, the surface charge and hence, the coating, can affect the uptake efficiency and transport within the plant. Zhu et al. (2012), who studied the fate of Au-NPs with different surface functionalization, observed that the Au-NPs with a negatively charged coating were the least efficiently attached onto the root surface prior to uptake but more efficiently transported to leaves once inside the plant, compared to positively charged Au-NPs.

Van Koetsem et al. (2016) studied the uptake of citrate-coated Ag-NPs in a hydroponic culture of Elodea canadensis and observed a dose-dependent reduction of $20-57 \%$ in the total $\mathrm{Ag}$ concentration in the growth medium within $72 \mathrm{~h}$ resulting in the accumulation of $25-110 \mathrm{mg} \mathrm{Ag} / \mathrm{kg}$ in plant biomass. The uptake of $\mathrm{Ag}^{+}$was approximately 4 and 8 times higher than the uptake of $\mathrm{Ag}$ NPs at the highest initial $\mathrm{Ag}$ doses tested $(0.5-1 \mathrm{mg} / \mathrm{L}$ ) (no significant difference at initial doses 0.05 - $0.25 \mathrm{mg} / \mathrm{L}$ ). Lowry et al. (2012a) investigated the fate of PVP-coated Ag-NPs in a freshwater emergent wetland and found that only a few percent of the spiked Ag ended up in plant tissue of Juncus effuses, Carex lurida, Panicum virgatum and Lobelia cardinalis. Furthermore, the majority of the accumulated Ag was found in the roots. Low translocation of Ag-NPs to aboveground biomass has also been observed in other rooted plants, such as Vigna unguiculata and Triticum aestivum in terrestrial environments (Wang et al. 2015). In the same study of Wang et al. (2015), they observed that $\mathrm{Ag}_{2} \mathrm{~S}$ was taken up by the plant roots to a somewhat larger extent than Ag-NPs. Also CuO- and 
ZnO-NPs are both mainly accumulated in the root zone of wetland plants Phragmites australis and

Jacob et al. (2013) showed that high phosphorus concentration can limit the uptake of $\mathrm{TiO}_{2}-\mathrm{NPs}$ in

Elodea Canadensis. Van Koetsem et al. (2016) found no link between the uptake of Ag-NPs and

phosphorus concentration but reported correlation between the uptake efficiency and conductivity and

specific ion content. This likely evidences that the ENM uptake efficiency is dependent of on occurrence of environmental transformations, which are determined by the ambient conditions. In

CWs, adsorption to organic matter will restrict plant uptake of ENMs as metal species bound to

organics are unavailable to plants. Also, aggregation (occurring e.g. due to high ionic strength

ENMs.

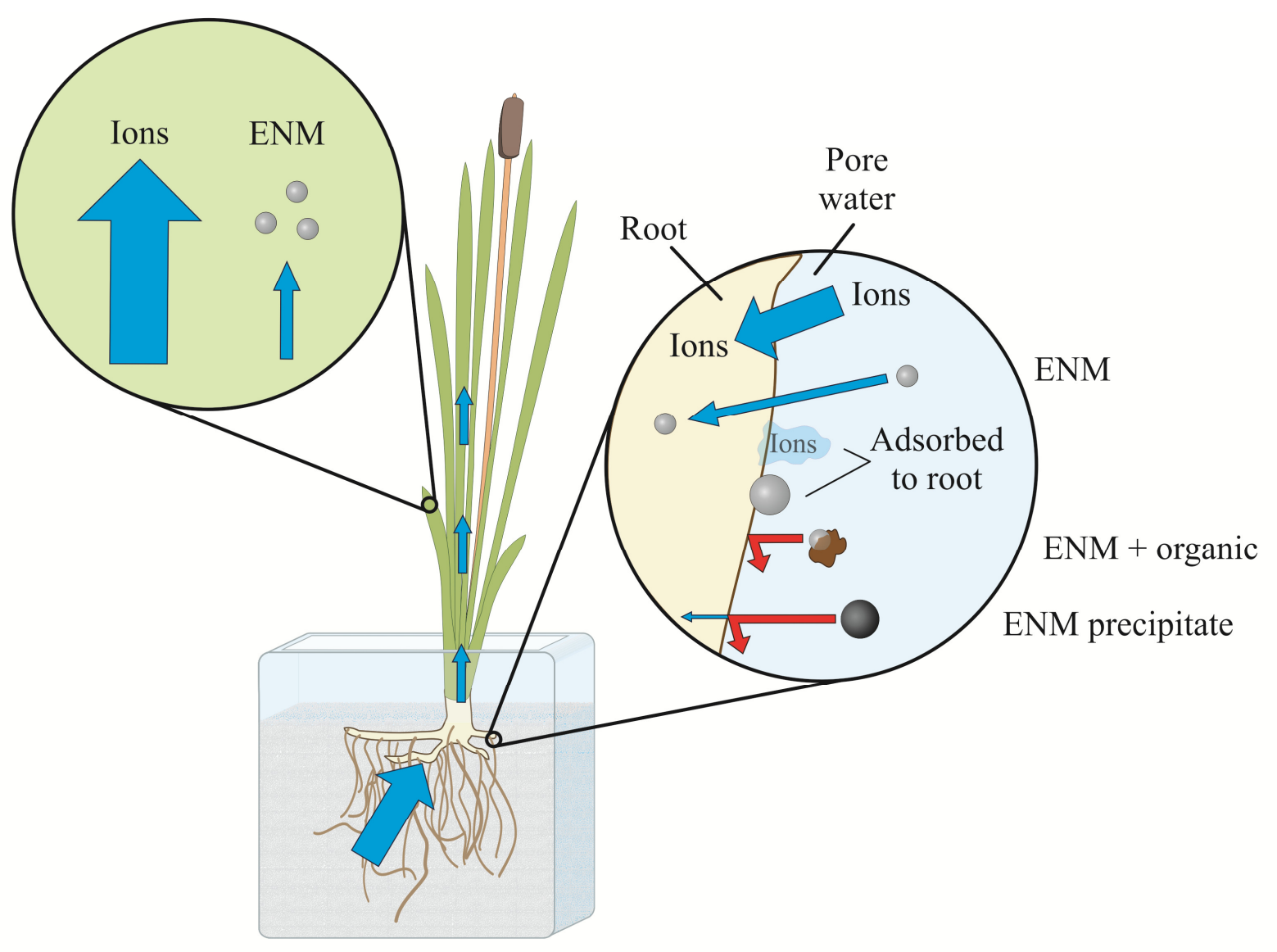

Figure 4 - Schematic illustration of the uptake of ENMs and metallic ions by plants. The translocation efficiency of the different species is indicated with the thickness of the arrows. The uptake and translocation of ENMs is restricted by their size and hence, it is likely that larger particles are less efficiently taken up by the plant and translocated within the plant than smaller ones. 


\section{Possible toxic effects of ENMs on the wastewater treatment process}

The toxicity of ENMs is undoubtedly related to the toxicity of the metal it is composed of. There are thus ENMs which are composed of an element ubiquitous in nature (e.g. Ti), ENMs which contain elements essential for cell structures (e.g. $\mathrm{Cu}$ and $\mathrm{Zn}$ ) and ENMs composed of metals toxic at low concentrations (e.g. Ag). It is thus logical that the toxic concentrations of the different ENMs vary greatly and that low concentrations of certain ENMs could even have positive effects on e.g. bacterial growth due to supplementation of essential elements. Several researchers have compared the toxicities of different types of ENMs. Luo et al. (2014) compared the toxicities of Au- and Ag-NPs on ammonia-oxidizing bacteria at concentrations $0.05-2 \mathrm{mg} / \mathrm{L}$, and found no adverse effects of Au-NPs on the bacterial community. Instead, Ag-NPs decreased the bacterial abundance and diversity resulting in 19 and $46 \%$ reduction in the ammoxidation activity at concentrations 0.05 and $2 \mathrm{mg} \mathrm{Ag} / \mathrm{L}$, respectively. Shah et al. (2014) observed adverse effects on the richness of a mixed soil microbial community when exposed to $\mathrm{Ag}$ - and $\mathrm{TiO}_{2}$-NPs at a concentration of $0.0625 \mathrm{mg} \mathrm{NPs} / \mathrm{kg}$ soil but $\mathrm{ZnO}$ and Cu-NPs did not affect the bacterial community structure. Ma et al. (2015), who studied the effect of $\mathrm{Ag}$ (ion and $\mathrm{NP}$ ), zero-valent $\mathrm{Fe}-\mathrm{NPs}, \mathrm{TiO}_{2}-\mathrm{NPs}$ and $\mathrm{CeO}_{2}-\mathrm{NPs}$ on the nitrification function and bacterial community structure, observed decreased nitrification efficiency and shifts in community structure only at prolonged exposure to high concentrations $(20 \mathrm{mg} / \mathrm{L})$ of $\mathrm{Ag}$-species. In the study of Moore et al. (2016), the impacts on sediment microbial consortia exposed to pulse Ag- or Cu-NPs were rather short term and showed evidence of environmental resilience.

The actual mechanism causing the toxicity is not entirely clear. Although many studies show that the release of free ions from the particles is the main cause of toxicity (see section 3.2), there are also studies showing that the toxic effects cannot be explained only by the amount of ions leaching from the ENMs and hence, there are likely to be particle specific effects as well (Yuan et al. 2013).

Hence, the properties of an ENM can influence its toxicity as well. For example, El Badawy et al. (2011) showed that the toxicity of Ag-NP to Bacillus sp. is dependent on the surface charge of the ENM because the chances for cell-particle interactions increase with decreasing magnitude of the negative zeta-potential. As a consequence, the most negatively charged Ag-NPs (uncoated and citrate- 
coated) exhibited complete growth inhibition at 75 and $600 \mu \mathrm{g} / \mathrm{L}$, the less negative PVP-coated AgNPs at $13 \mu \mathrm{g} / \mathrm{L}$ and the positively charged branched polyethyl-eneimine (BPEI)-coated Ag-NPs at 3 $\mu \mathrm{g} / \mathrm{L}$. Also the size of the ENM could be significant in defining its toxicity. Choi \& $\mathrm{Hu}(2008)$ found that the fraction of Ag-NPs less than $5 \mathrm{~nm}$ in the suspension correlated with the inhibition of nitrifying bacteria. However, Levard et al. (2013a), who studied the transformations of Ag-NPs and their toxicity to higher organisms, found little correlation between the size of the aggregates and the observed toxicity and suggested that the reduction in $\mathrm{Ag}^{+}$due to $\mathrm{AgCl}$ formation had the dominant toxicity decreasing effect.

When ENMs undergo transformations in the environment, it is likely that their toxicity is altered. Sulfidation has been observed to be an important mechanism at decreasing the toxicity of Ag-NPs to bacteria (Reinsch et al. 2012). Moreover, Choi et al. (2009) showed that sulfide had the most pronounced effect on relieving the toxicity of Ag-NPs among the tested ligands $\left(\mathrm{SO}_{4}{ }^{2-}, \mathrm{Cl}^{-}, \mathrm{PO}_{4}{ }^{3-}\right.$, EDTA). In this study, the inhibition of nitrification was reduced by $80 \%$ in the presence of $0.5 \mathrm{mg} / \mathrm{L}$ sulfide and $1 \mathrm{mg} / \mathrm{L} \mathrm{Ag}$ (as Ag-NPs). In addition, other environmental factors such as dissolved oxygen concentration and ionic strength, can affect the dissolution/aggregation behavior of ENMs and thereby, affect their toxicity on organisms (see Section 3).

It should be noted that comparing the toxicities of ENMs and their transformation products is not straightforward since their toxicities can depend on the target organism among other factors. Choi et al. (2008) observed that $\mathrm{AgCl}$ colloids and Ag-NPs were less toxic to Escherichia coli than $\mathrm{Ag}^{+}$but nitrifying bacteria were especially susceptible to $\mathrm{Ag}-\mathrm{NPs}$, more than to $\mathrm{Ag}^{+}$and $\mathrm{AgCl}$ colloids: $1 \mathrm{mg}$ $\mathrm{Ag} / \mathrm{L}$ as $\mathrm{Ag}-\mathrm{NPs}$ inhibited the microbial respiration by $86 \%$ while in the case of $\mathrm{Ag}^{+}$and $\mathrm{AgCl}$ colloids the inhibitory effect was only approximately $45 \%$. In a similar experiment, Choi \& Hu (2008) observed that the presence of $0.14 \mathrm{mg} \mathrm{Ag/L}$ of polyvinyl alcohol (PVA) coated Ag-NPs, $0.27 \mathrm{mg}$ $\mathrm{Ag} / \mathrm{L}$ of $\mathrm{Ag}^{+}$and $0.25 \mathrm{mg} \mathrm{Ag} / \mathrm{L}$ of $\mathrm{AgCl}$ colloids inhibited the growth of nitrifiers by $50 \%$.

There are some studies where the effects of ENMs on actual wastewater treatment processes have been investigated. Alito \& Gunsch (2014) studied COD and ammonium removal efficiencies in laboratoryscale sequencing batch reactors (SBRs) which were spiked with citrate- and GA-coated Ag-NPs $(0.2$ 
$\mathrm{mg} / \mathrm{L}$ ). Although the treatment efficiency was recovered within $24 \mathrm{~h}$, the COD and ammonium removal efficiencies were initially affected by $20-30 \%$ and by $1-15 \%$, respectively. When the effect of $\mathrm{CeO}_{2}$-NPs on the nitrogen removal process in an SBR was studied by Hou et al. (2015), they observed no significant effect on total nitrogen removal at $1 \mathrm{mg} / \mathrm{L}$ but at 10 and $50 \mathrm{mg} / \mathrm{L}$ the total nitrogen removal efficiency reduced by approximately $30 \%$. The resilience of the bacterial communities in sludge is probably related to the protection by the EPS matrix which accounts for the floc formation in activated sludge (Henriques and Love 2007). The adsorption of ENMs by EPS can decrease the diffusive transportation through the EPS (Choi et al. 2010) and thus, protect the bacteria from the ENMs.

In CWs, the cells habiting the biofilm are better protected against toxins than planktonic cells due to EPS (Choi et al. 2010), similarly to sludge flocs. A study on wastewater dwelling bacteria showing that the community profile of a biofilm culture did not change after exposure to $200 \mathrm{mg} / \mathrm{L}$ of $\mathrm{Ag}-\mathrm{NPs}$, while nearly all planktonic bacteria died at $1 \mathrm{mg} / \mathrm{L}$ illustrates the protective effects of EPS (Sheng and Liu 2011). However, the biofilm bacteria can still experience stress due to the presence of ENMs (Hou et al. 2015). Under stress, bacteria are unable to protect themselves from intracellular reactive oxygen species which can damage cellular structures when accumulating in the cell (Choi \& Hu 2008). The concentrations of ENMs in the biofilm increase during the lifetime of a CW. Lesage et al. (2007) studied the accumulation of $\mathrm{Zn}$ and other bulk metals in a HSSF CW and measured concentrations reaching $1400 \mathrm{mg} \mathrm{Zn/kg} \mathrm{dry} \mathrm{matter} \mathrm{in} \mathrm{the} \mathrm{wetland} \mathrm{substrate} \mathrm{after} 6$ years of operation. During the sampling they measured an average $\mathrm{Zn}$ concentration of $120 \mu \mathrm{g} / \mathrm{L}$ in in the influent. As this is more than 100 times higher than the concentration predicted for ZnO-NPs in domestic wastewater $(1 \mu \mathrm{g} / \mathrm{L}$; calculated with a conservative $70 \%$ removal efficiency (Markus et al. 2013) from a modeled value for wastewater effluent $0.29 \mu \mathrm{g} / \mathrm{L}$ (Sun et al. 2014)), the likelihood of NP induced toxicity seems irrelevant at current production volumes.

\section{Possible release of ENMs from $\mathrm{CW}$}


clogging, by removing the gravel, washing it and returning it back to the CW, ENM containing wastewater can be produced.

Due to the affinity of ENMs for organic matter as discussed earlier (see section 3.4) and the efficient removal of suspended solids in CWs (e.g. Vymazal 2009) the concentrations of ENMs released from

CWs are during normal operation likely to be low and comparable to activated sludge treatment systems. Over the years the CW bed becomes more filled with SS and plant roots and this can result in topographic and vegetative heterogeneities creating faster and slower flow paths through the wetland substrate (Dierberg et al. 2005). Fast flow of influent through the CW (i.e. short-circuiting) may decrease the removal efficiency of ENMs similarly to other contaminants. Also, active aeration may cause mixing of a fraction of influent with effluent especially in systems with a small length-to-width ratio. In addition, sudden changes in the influent flow rate or aeration may cause detachment of biofilm and subsequent increased discharge of ENMs embedded in the biofilm.

Conventional CWs sludge is not needed to be removed during operation. In French type VF CWs, where unsettled wastewater is treated, the sludge layer is occasionally removed, and in this case, if the sludge is applied to (agricultural) land, contamination of the soil by ENMs may occur (Deng et al. 2014). The mass of the sludge deposit corresponds to approximately $40 \%$ of the SS introduced with the wastewater (Molle et al. 2005) and due to the mineralization of organic matter over the years, the metal concentration in the sludge deposit layer is bound to increase. Molle (2003) measured concentrations of e.g. $\mathrm{Cu}$ and $\mathrm{Zn}$ in a sludge deposit collected after 11 years of operation and stored since collection for 5 years. The concentrations found $(196 \mathrm{mg} \mathrm{Cu} / \mathrm{kg}$ dry matter and $221 \mathrm{mg} \mathrm{Zn/kg}$ dry matter) would not have restricted the application of the sludge on agricultural land (European Commission 1986). The European sewage sludge directive does not directly concern ENMs in sludge. Measuring the concentration of ENMs in sludge cannot be required because of the lack of reliable techniques to detect ENMs in environmental samples (Ganzleben et al. 2011). released upon composting. Vymazal et al. (2010) studied the accumulation of metals in the aboveground tissue of Phalaris arundinacea growing in a HSSF CW treating domestic wastewater. 
The values for annual accumulated mass in the aboveground tissue per given area (so called standing stock) were for e.g. $\mathrm{Zn}$ and $\mathrm{Cu} 28.5 \mathrm{~g} \mathrm{Zn} / \mathrm{m}^{2} / \mathrm{a}$ and $8.8 \mathrm{~g} \mathrm{Cu} / \mathrm{m}^{2} / \mathrm{a}$. If we assume similar uptake efficiency for $\mathrm{ZnO}-\mathrm{NPs}$ as for $\mathrm{Zn}^{2+}$ and estimate the $\mathrm{ZnO}-\mathrm{NP}: \mathrm{Zn}$ ratio in domestic wastewater to be 0.008 (120 $\mu \mathrm{g} \mathrm{Zn/L} \mathrm{(Lesage} \mathrm{et} \mathrm{al.} \mathrm{2007)} \mathrm{and} 1 \mu \mathrm{g}$ ZnO-NPs/L; the latter calculated with a conservative $70 \%$ removal efficiency (Markus et al. 2013) from a modeled value for wastewater effluent $0.29 \mu \mathrm{g} / \mathrm{L}$ (Sun et al. 2014)), the standing stock for $\mathrm{ZnO}-\mathrm{NP}$ in $P$. arundinacea would be $0.2 \mathrm{~g} \mathrm{Zn} / \mathrm{m}^{2} / \mathrm{a}$. In comparison to the bulk metal counterpart, the mass of ENMs is thus predicted to be low and the risk posed by the ENM containing plant material from CWs seems insignificant.

\section{Conclusions and perspectives}

ENMs are present in our everyday household products. The increasing production volumes make it important to study the fate of ENMs in wastewater treatment systems to reliably estimate the environmental risk they pose.

During the usage of an ENM containing product, ENMs can be released to the washing water and end up in wastewater. In the sewer system, ENMs are likely to bind with organic matter and some types may sulfidized but little losses to the sewer biofilm are expected. The current estimates on the ENM concentration in wastewater reaching the treatment plant vary from some $\mu \mathrm{g} / \mathrm{L}$ to hundreds of $\mu \mathrm{g} / \mathrm{L}$ depending on the type of ENM. Although these values are low and unlikely to cause toxicity to microbial communities in CWs, caution is warranted due to the expected increase in the production of ENMs in the future.

The ENMs are expected to further transform in CWs. The type and extent of these transformations depend on the type of the ENM and the prevailing environmental conditions in the CW. Some differences in the fate of ENMs in HSSF CWs versus VSSF CWs can thus be expected due to e.g. different dissolved oxygen conditions. In general, important transformations that are likely to occur in CWs are sulfidation, sorption onto organic matter and other solids and heteroaggregation with suspended particles. Plant uptake is likely to have a minor role in the removal of ENM from the water phase, although adsorption of ENMs onto the root surfaces can be substantial. Hence, wetland plants 
can play an important role in ENM immobilization in the rhizosphere. The concentrations of ENMs released from a CW with effluent, harvested plant material and (in some special cases) sludge are expected to be low due to the efficient retention of ENMs within the substrate. CWs are thus not predicted to be potential point sources of ENMs in surface waters during normal operation.

Future research should focus on exploring (temporary) circumstances which possibly can cause the discharge of ENMs from CWs. Clogging and subsequent short-circuiting can decrease the overall treatment efficiency and hence, it can also affect the retention of ENMs. Biofilm which immobilizes ENMs can be detached from the CW substrate due to e.g. sudden changes in flow rate and aeration, and ENMs can also be discharged by being washed out from the CW. Although sulfidation in CWs seems unavoidable, it is impossible to say to what extent it occurs. This may be important for the bioavailability of the metal species as ions are better taken up by plants than ENMs or it may impact the toxicity caused on the biofilm. The biofilm is not predicted to be adversely affected by the ENMs in the water phase but in the long term the accumulating ENMs may become toxic to the microorganisms. However, the fraction of ENMs in the total load of metals in CWs being very low, the primary toxic effects are likely to be caused by the bulk metals instead of ENMs at current production volumes.

\section{References}

Alito CL, Gunsch CK (2014) Assessing the effects of silver nanoparticles on biological nutrient removal in bench-scale activated sludge sequencing batch reactors. Environ Sci Technol 48:970976.

Barber LB, Leenheer JA, Noyes TI, Stiles EA (2001) Nature and transformation of dissolved organic matter in treatment wetlands. Environ Sci Technol 35:4805-4816. doi: 10.1021/es010518i

Ben-Moshe T, Dror I, Berkowitz B (2010) Transport of metal oxide nanoparticles in saturated porous media. Chemosphere 81:387-393. doi: 10.1016/j.chemosphere.2010.07.007

Benn TM, Westerhoff P (2008) Nanoparticle silver released into water from commercially available sock fabrics. Environ Sci Technol 42:4133-4139. doi: 10.1021/es7032718 
Blaser SA, Scheringer M, MacLeod M, Hungerbühler K (2008) Estimation of cumulative aquatic exposure and risk due to silver: Contribution of nano-functionalized plastics and textiles. Sci Total Environ 390:396-409. doi: 10.1016/j.scitotenv.2007.10.010

Brunetti G, Donner E, Laera G, et al (2015) Fate of zinc and silver engineered nanoparticles in sewerage networks. Water Res 77:72-84. doi: 10.1016/j.watres.2015.03.003

Caselles-Osorio A, Puigagut J, Segú E, et al (2007) Solids accumulation in six full-scale subsurface flow constructed wetlands. Water Res 41:1388-1398. doi: 10.1016/j.watres.2006.12.019

Choi O, Clevenger TE, Deng B, et al (2009) Role of sulfide and ligand strength in controlling nanosilver toxicity. Water Res 43:1879-1886. doi: 10.1016/j.watres.2009.01.029

Choi O, Deng KK, Kim NJ, et al (2008) The inhibitory effects of silver nanoparticles, silver ions, and silver chloride colloids on microbial growth. Water Res 42:3066-3074. doi: 10.1016/j.watres.2008.02.021

Choi $\mathrm{O}, \mathrm{Hu} \mathrm{Z}$ (2008) Size dependent and reactive oxygen species related nanosilver toxicity to nitrifying bacteria. Environ Sci Technol 42:4583-4588. doi: 10.1021/es703238h

Choi O, Yu CP, Esteban Fernández G, Hu Z (2010) Interactions of nanosilver with Escherichia coli cells in planktonic and biofilm cultures. Water Res 44:6095-6103. doi: 10.1016/j.watres.2010.06.069

Christian P, Von Der Kammer F, Baalousha M, Hofmann T (2008) Nanoparticles: Structure, properties, preparation and behaviour in environmental media. Ecotoxicology 17:326-343. doi: 10.1007/s10646-008-0213-1

Cleveland D, Long SE, Pennington PL, et al (2012) Pilot estuarine mesocosm study on the environmental fate of Silver nanomaterials leached from consumer products. Sci Total Environ 421-422:267-272. doi: 10.1016/j.scitotenv.2012.01.025

Cornelis G, Doolette C, Thomas M, et al (2012) Retention and dissolution of engineered silver nanoparticles in natural soils. Soil Sci Soc Am J 76:891. doi: 10.2136/sssaj2011.0360

Coutris C, Joner EJ, Oughton DH (2012) Aging and soil organic matter content affect the fate of silver nanoparticles in soil. Sci Total Environ 420:327-333. doi: 10.1016/j.scitotenv.2012.01.027

Delay M, Dolt T, Woellhaf A, et al (2011) Interactions and stability of silver nanoparticles in the 
aqueous phase: Influence of natural organic matter (NOM) and ionic strength. J Chromatogr A 1218:4206-4212. doi: 10.1016/j.chroma.2011.02.074

Deng Y, White JC, Xing B (2014) Interactions between engineered nanomaterials and agricultural crops: implications for food safety. J Zhejiang Univ Sci A 15:552-572. doi: 10.1631/jzus.A1400165

Dierberg FE, Juston JJ, DeBusk TA, et al (2005) Relationship between hydraulic efficiency and phosphorus removal in a submerged aquatic vegetation-dominated treatment wetland. Ecol Eng 25:9-23. doi: 10.1016/j.ecoleng.2004.12.018

Dietz KJ, Herth S (2011) Plant nanotoxicology. Trends Plant Sci 16:582-589. doi: 10.1016/j.tplants.2011.08.003

Dignac MF, Ginestet P, Rybacki D, et al (2000) Fate of wastewater organic pollution during activated sludge treatment: Nature of residual organic matter. Water Res 34:4185-4194. doi: 10.1016/S0043-1354(00)00195-0

Donner E, Scheckel K, Sekine R, et al (2015) Non-labile silver species in biosolids remain stable throughout 50 years of weathering and ageing. Environ Pollut 205:78-86. doi: 10.1016/j.envpol.2015.05.017

ECHA (2012) Guidance on information requirements and chemicalsafetey assessment - RIsk management measures and operational conditions.

El Badawy AM, Scheckel KG, Suidan M, Tolaymat T (2012) The impact of stabilization mechanism on the aggregation kinetics of silver nanoparticles. Sci Total Environ 429:325-331. doi: 10.1016/j.scitotenv.2012.03.041

El Badawy AM, Silva RG, Morris B, et al (2011) Surface charge-dependent toxicity of silver nanoparticles. Environ Sci Technol 45:283-287. doi: 10.1021/es1034188

European Commission (1986) Council Directive of 12 June 1986 on the protection of the environment, and in particular of the soil, when sewage sludge is used in agriculture. Off J Eur Communities 4:6-12.

Fabrega J, Fawcett SR, Renshaw JC, Lead JR (2009) Silver nanoparticle impact on bacterial growth: Effect of pH, concentration, and organic matter. Environ Sci Technol 43:7285-7290. doi: 
576

577

578

579

580

581

582

583

584

585

586

587

588

589

590

591

592

593

594

595

596

597

598

599

600

601

602

Gallego-Urrea JA, Perez Holmberg J, Hassellöv M (2014) Influence of different types of natural organic matter on titania nanoparticle stability: effects of counter ion concentration and $\mathrm{pH}$. Environ Sci Nano 1:181. doi: 10.1039/c3en00106g

Ganesh R, Smeraldi J, Hosseini T, et al (2010) Evaluation of nano copper removal and toxicity in municipal wastewaters. Environ Sci Technol 44:7808-7813.

Ganzleben, C., Pelsy, F., Hansen, S., Corden, C., Grebot, B., Sobey M (2011) Review of environmental legislation for the regulatory control of nanomaterials. 210.

Glatzel S, Kalbitz K, Dalva M, Moore T (2003) Dissolved organic matter properties and their relationship to carbon dioxide efflux from restored peat bogs. Geoderma 113:397-411. doi: 10.1016/S0016-7061(02)00372-5

Gottschalk F, Nowack B (2011) The release of engineered nanomaterials to the environment. J Environ Monit 13:1145-1155. doi: 10.1039/c0em00547a

Henriques IDS, Love NG (2007) The role of extracellular polymeric substances in the toxicity response of activated sludge bacteria to chemical toxins. Water Res 41:4177-4185. doi: 10.1016/j.watres.2007.05.001

Hotze EM, Phenrat T, Lowry G V, Mellon C (2010) Nanoparticle aggregation: challenges to understanding transport and reactivity in the environment. J Environ Qual 39:1909-1924. doi: $10.2134 /$ jeq2009.0462

Hou J, You G, Xu Y, et al (2015) Effects of $\mathrm{CeO} 2$ nanoparticles on biological nitrogen removal in a sequencing batch biofilm reactor and mechanism of toxicity. Bioresour Technol 191:73-8. doi: 10.1016/j.biortech.2015.04.123

Hou L, Li K, Ding Y, et al (2012) Removal of silver nanoparticles in simulated wastewater treatment processes and its impact on COD and NH 4 reduction. Chemosphere 87:248-252. doi: 10.1016/j.chemosphere.2011.12.042

Hou L, Xia J, Li K, et al (2013) Removal of ZnO nanoparticles in simulated wastewater treatment processes and its effects on COD and NH4-N reduction. Water Sci Technol 67:254-260. doi: $10.2166 /$ wst. 2012.530 
603

604

605

606

607

608

609

610

611

612

613

614

615

616

617

618

619

620

621

622

623

624

625

626

627

628

629

630

Huynh KA, Chen KL (2011) Aggregation kinetics of citrate and polyvinylpyrrolidone coated silver nanoparticles in monovalent and divalent electrolyte solutions. Environ Sci Technol 45:55645571. doi: 10.1021/es200157h

Jacob DL, Borchardt JD, Navaratnam L, et al (2013) Uptake and translocation of Ti from nanoparticles in crops and wetland plants. Int $\mathrm{J}$ Phytoremediation 15:142-153. doi: $10.1080 / 15226514.2012 .683209$

Jiang FY, Chen X, Luo AC (2009) Iron plaque formation on wetland plants and its influence on phosphorus, calcium and metal uptake. Aquat Ecol 43:879-890. doi: 10.1007/s10452-009-9241-

$z$

Kadlec RH, Wallace SD (2009) Treatment Wetlands, 2nd ed. CRC Press, Boca Raton

Kaegi R, Ulrich A, Sinnet B, et al (2008) Synthetic TiO2 nanoparticle emission from exterior facades into the aquatic environment. Environ Pollut 156:233-239. doi: 10.1016/j.envpol.2008.08.004

Kaegi R, Voegelin A, Ort C, et al (2013) Fate and transformation of silver nanoparticles in urban wastewater systems. Water Res 47:3866-3877. doi: 10.1016/j.watres.2012.11.060

Kaegi R, Voegelin A, Sinnet B, et al (2011) Behavior of metallic silver nanoparticles in a pilot wastewater treatment plant. Environ Sci Technol 45:3902-3908. doi: 10.1021/es1041892

Kanel SR, Flory J, Meyerhoefer A, et al (2015) Influence of natural organic matter on fate and transport of silver nanoparticles in saturated porous media: laboratory experiments and modeling. J Nanoparticle Res. doi: 10.1007/s11051-015-2956-y

Katsoyiannis A, Samara C (2007) The fate of dissolved organic carbon (DOC) in the wastewater treatment process and its importance in the removal of wastewater contaminants. Environ Sci Pollut Res Int 14:284-292. doi: 10.1065/espr2006.05.302

Keller AA, Lazareva A (2013) Predicted releases of engineered nanomaterials: from global to regional to local. Environ Sci Technol Lett 1:65-70. doi: 10.1021/ez400106t

Kent RD, Oser JG, Vikesland PJ (2014) Controlled evaluation of silver nanoparticle sulfidation in a full-scale wastewater treatment plant. Environ Sci Technol 48:8564-8572. doi: $10.1021 / \mathrm{es} 404989 \mathrm{t}$

Kim B, Park CS, Murayama M, Hochella MF (2010) Discovery and characterization of silver sulfide 
nanoparticles in final sewage sludge products. Environ Sci Technol 44:7509-7514. doi:

632

633

634

635

636

637

638

639

640

641

642

643

644

645

646

647

648

649

650

651

652

653

654

655

656

657

658 $10.1021 / \mathrm{es} 101565 \mathrm{j}$

Kiser MA, Ryu H, Jang H, et al (2010) Biosorption of nanoparticles to heterotrophic wastewater biomass. Water Res 44:4105-4114. doi: 10.1016/j.watres.2010.05.036

Krämer U (2010) Metal hyperaccumulation in plants. Annu Rev Plant Biol 61:517-34. doi: 10.1146/annurev-arplant-042809-112156

Lesage E, Rousseau D, Meers E, et al (2007) Accumulation of metals in a horizontal subsurface flow constructed wetland treating domestic wastewater in Flanders, Belgium. Sci Total Environ 380:102-115. doi: 10.1016/j.scitotenv.2006.10.055

Levard C, Hotze EM, Colman BP, et al (2013a) Sulfidation of silver nanoparticles: Natural antidote to their toxicity. Environ Sci Technol 47:13440-13448. doi: 10.1021/es403527n

Levard C, Hotze EM, Lowry G V., Brown GE (2012) Environmental transformations of silver nanoparticles: Impact on stability and toxicity. Environ Sci Technol 46:6900-6914. doi: $10.1021 / \mathrm{es} 2037405$

Levard C, Mitra S, Yang T, et al (2013b) Effect of chloride on the dissolution rate of silver nanoparticles and toxicity to E. coli. Environ Sci Technol 47:5738-5745. doi: 10.1021/es400396f

Levard C, Reinsch BC, Michel FM, et al (2011) Sulfidation processes of PVP-coated silver nanoparticles in aqueous solution: Impact on dissolution rate. Environ Sci Technol 45:52605266. doi: 10.1021/es2007758

Li L, Hartmann G, Schuster M (2013) Quantification of nanoscale silver particles removal and release from municipal wastewater treatment plants in Germany. Environ Sci Technol 47:7317-7323.

Li M, Zhu L, Lin D (2011) Toxicity of ZnO nanoparticles to Escherichia coli: Mechanism and the influence of medium components. Environ Sci Technol 45:1977-1983. doi: 10.1021/es102624t

Li X, Lenhart JJ (2012) Aggregation and dissolution of silver nanoparticles in natural surface water. Environ Sci Technol 46:5378-5386. doi: 10.1021/es204531y

Li X, Lenhart JJ, Walker HW (2010) Dissolution-accompanied aggregation kinetics of silver nanoparticles. Langmuir 26:16690-16698. doi: 10.1021/la101768n

Limbach LK, Bereiter R, Galli R, Stark WJ (2008) Removal of oxide nanoparticles in a model waste 
water treatment plant. Environ Sci Technol 42:5828-5833.

660

661

662

663

664

665

666

667

668

669

670

671

672

673

674

675

676

677

678

679

680

681

682

683

684

685

686

Lin D, Tian X, Wu F, Xing B (2010) Fate and transport of engineered nanomaterials in the environment. J Environ Qual 39:1896-1908. doi: 10.2134/jeq2009.0423

Liu J, Hurt RH (2010) Ion release kinetics and particle persistence in aqueous nano silver colloids. Environ Sci Technol 44:2169-2175.

Liu J, Pennell KG, Hurt RH (2011) Kinetics and mechanisms of nanosilver oxysulfidation. Environ Sci Technol 45:7345-7353. doi: 10.1021/es201539s

Lombi E, Donner E, Taheri S, et al (2013) Transformation of four silver/silver chloride nanoparticles during anaerobic treatment of wastewater and post-processing of sewage sludge. Environ Pollut 176:193-197. doi: 10.1016/j.envpol.2013.01.029

Lombi E, Donner E, Tavakkoli E, et al (2012) Fate of zinc oxide nanoparticles during anaerobic digestion of wastewater and post-treatment processing of sewage sludge. Environ Sci Technol 46:9089-9096. doi: 10.1021/es301487s

Lowry G V., Espinasse BP, Badireddy AR, et al (2012a) Long-term transformation and fate of manufactured $\mathrm{Ag}$ nanoparticles in a simulated large scale freshwater emergent wetland. Environ Sci Technol 46:7027-7036. doi: 10.1021/es204608d

Lowry G V., Gregory KB, Apte SC, Lead JR (2012b) Transformations of nanomaterials in the environment. Environ Sci Technol 46:6893-6899. doi: 10.1021/es300839e

Luo Z, Chen Z, Qiu Z, et al (2014) Gold and silver nanoparticle effects on ammonia-oxidizing bacteria $\begin{array}{llll}\text { cultures } \quad \text { ander } & \text { ammoxidation. }\end{array}$ 10.1016/j.chemosphere.2014.01.075

Ma R, Levard C, Michel FM, et al (2013) Sulfidation mechanism for Zinc oxide nanoparticles and the effect of sulfidation on their solubility. 2527-2534.

Ma R, Stegemeier J, Levard C, et al (2014) Sulfidation of copper oxide nanoparticles and properties of resulting copper sulfide. Environ Sci Nano 1:347-357. doi: 10.1039/C4EN00018H

Ma Y, Metch JW, Vejerano EP, et al (2015) Microbial community response of nitrifying sequencing batch reactors to silver, zero-valent iron, titanium dioxide and cerium dioxide nanomaterials. Water Res 68:87-97. doi: 10.1016/j.watres.2014.09.008 
Markus AA, Parsons JR, Roex EWM, et al (2013) Predicting the contribution of nanoparticles (Zn, Ti, $\mathrm{Ag}$ ) to the annual metal load in the Dutch reaches of the Rhine and Meuse. Sci Total Environ 456-457:154-160. doi: 10.1016/j.scitotenv.2013.03.058

Metreveli G, Philippe A, Schaumann GE (2015) Disaggregation of silver nanoparticle homoaggregates in a river water matrix. Sci Total Environ 535:35-44. doi: 10.1016/j.scitotenv.2014.11.058

Mitrano DM, Rimmele E, Wichser A, et al (2014) Presence of nanoparticles in wash water from conventional silver and nano-silver textiles. ACS Nano 8:7208-7219. doi: 10.1021/nn502228w

Molle P (2003) Filtres plantes de roseaux: limites hydrauliques et rétention du phosphore. Université Montpellier II

Molle P, Liénard A, Boutin C, et al (2005) How to treat raw sewage with constructed wetlands: an overview of the French systems. Water Sci Technol 51:11-21.

Moore JD, Stegemeier JP, Bibby K, et al (2016) Impacts of pristine and transformed $\mathrm{Ag}$ and $\mathrm{Cu}$ engineered nanomaterials on surficial sediment microbial communities appear short-lived. Environ Sci Technol 50:2641-2651. doi: 10.1021/acs.est.5b05054

Navarro E, Baun A, Behra R, et al (2008) Environmental behavior and ecotoxicity of engineered nanoparticles to algae, plants, and fungi. Ecotoxicology 17:372-386. doi: 10.1007/s10646-0080214-0

Odzak N, Kistler D, Behra R, Sigg L (2014) Dissolution of metal and metal oxide nanoparticles in aqueous media. Environ Pollut 191:132-138. doi: 10.1016/j.envpol.2014.04.010

Piccapietra F, Sigg L, Behra R (2012) Colloidal stability of carbonate-coated silver nanoparticles in synthetic and natural freshwater. Environ Sci Technol 46:818-825. doi: 10.1021/es202843h

Pinney ML, Westerhoff PK, Baker L (2000) Transformations in dissolved organic carbon through constructed wetlands. Water Res 34:1897-1911. doi: 10.1016/S0043-1354(99)00330-9

Puay N-Q, Qiu G, Ting Y-P (2015) Effect of Zinc oxide nanoparticles on biological wastewater treatment in a sequencing batch reactor. J Clean Prod 88:139-145. doi: 10.1016/j.jclepro.2014.03.081

Quanrud DM, Karpiscak MM, Lansey KE, Arnold RG (2004) Transformation of effluent organic 
matter during subsurface wetland treatment in the Sonoran Desert. Chemosphere 54:777-788. doi: 10.1016/j.chemosphere.2003.08.020

717

Quik JTK, Velzeboer I, Wouterse MJ, et al (2014) Heteroaggregation and sedimentation rates for nanomaterials in natural waters. Water Res 48:269-279. doi: 10.1016/j.watres.2013.09.036

Rathnayake S, Unrine JM, Judy J, et al (2014) Multitechnique investigation of the $\mathrm{pH}$ dependence of phosphate induced transformations of $\mathrm{ZnO}$ nanoparticles. Environ Sci Technol 48:4757-4764. doi: $10.1021 / \mathrm{es} 404544 \mathrm{w}$

Reinsch BC, Levard C, Li Z, et al (2012) Sulfidation of silver nanoparticles decreases Escherichia coli growth inhibition. Environ Sci Technol 46:6992-7000. doi: 10.1021/es203732x

Salt DE, Blaylock M, Kumar NP, et al (1995) Phytoremediation: a novel strategy for the removal of toxic metals from the environment using plants. Bio/technology 13:468-474. doi: $10.1038 / \mathrm{nbt} 0595-468$

Shah V, Jones J, Dickman J, Greenman S (2014) Response of soil bacterial community to metal nanoparticles in biosolids. J Hazard Mater 274:399-403. doi: 10.1016/j.jhazmat.2014.04.003

Sheng Z, Liu Y (2011) Effects of silver nanoparticles on wastewater biofilms. Water Res 45:60396050. doi: 10.1016/j.watres.2011.08.065

Song JE, Phenrat T, Marinakos S, et al (2011) Hydrophobic Interactions Increase Attachment of Gum Arabic- and PVP-Coated Ag Nanoparticles to Hydrophobic Surfaces. Environ Sci Technol 45:5988-5995.

Sotiriou GA, Pratsinis SE (2010) Antibacterial activity of nanosilver ions and particles. Environ Sci Technol 44:5649-5654. doi: 10.1021/es101072s

Stankus DP, Lohse SE, Hutchison JE, Nason J a. (2011) Interactions between natural organic matter and gold nanoparticles stabilized with different organic capping agents. Environ Sci Technol 45:3238-3244. doi: 10.1021/es102603p

Sun TY, Gottschalk F, Hungerbühler K, Nowack B (2014) Comprehensive probabilistic modelling of environmental emissions of engineered nanomaterials. Environ Pollut 185:69-76. doi: 10.1016/j.envpol.2013.10.004

Thalmann B, Voegelin A, Sinnet B, et al (2014) Sulfidation kinetics of silver nanoparticles reacted 
744

745

746

747

Van Hoecke K, De Schamphelaere K a C, Van Der Meeren P, et al (2011) Aggregation and ecotoxicity of $\mathrm{CeO} 2$ nanoparticles in synthetic and natural waters with variable $\mathrm{pH}$, organic matter concentration and ionic strength. Environ Pollut 159:970-976. doi: 10.1016/j.envpol.2010.12.010

Van Koetsem F, Geremew TT, Wallaert E, et al (2015) Fate of engineered nanomaterials in surface water: Factors affecting interactions of $\mathrm{Ag}$ and $\mathrm{CeO} 2$ nanoparticles with (re)suspended sediments. Ecol Eng 80:140-150. doi: 10.1016/j.ecoleng.2014.07.024

Van Koetsem F, Xiao Y, Luo Z, Du Laing G (2016) Impact of water composition on association of Ag and $\mathrm{CeO} 2$ nanoparticles with aquatic macrophyte Elodea canadensis. Environ Sci Pollut Res 23:5277-5287. doi: 10.1007/s11356-015-5708-8

Verbanck M, Vanderborght J, Wollast R (1989) Major ion content of urban wastewater: assessment of per capita loading. Res J Water Pollut Control Fed 61:1722-1728.

Voice TC, Weber WJ (1983) Sorption of hydrophobic compounds by sediments, soils and suspended solids-I. Theory and background. Water Res 17:1433-1441. doi: 10.1016/0043-1354(83)90276-2

von der Kammer F, Ferguson PL, Holden PA, et al (2012) Analysis of engineered nanomaterials in complex matrices (environment and biota): General considerations and conceptual case studies. Environ Toxicol Chem 31:32-49. doi: 10.1002/etc.723

Vymazal J (2009) The use constructed wetlands with horizontal sub-surface flow for various types of wastewater. Ecol Eng 35:1-17. doi: 10.1016/j.ecoleng.2008.08.016

Vymazal J (2011) Long-term performance of constructed wetlands with horizontal sub-surface flow: Ten case studies from the Czech Republic. Ecol Eng 37:54-63. doi: 10.1016/j.ecoleng.2009.11.028

Vymazal J, Kröpfelová L, Švehla J, Štíchová J (2010) Can multiple harvest of aboveground biomass enhance removal of trace elements in constructed wetlands receiving municipal sewage? Ecol Eng 36:939-945. doi: 10.1016/j.ecoleng.2010.04.010

Wang P, Menzies NW, Lombi E, et al (2015) Silver sulfide nanoparticles (Ag2S-NPs) are taken up by plants and are phytotoxic. Nanotoxicology 5390:1-9. doi: 10.3109/17435390.2014.999139 
Weiss J, Hondzo M, Biesboer D, Semmens M (2006) Laboratory study of heavy metal phytoremediation by three wetland macrophytes. Int J Phytoremediation 8:245-259. doi: $10.1080 / 15226510600846798$

Wiessner A, Kappelmeyer U, Kuschk P, Kästner M (2005) Sulphate reduction and the removal of carbon and ammonia in a laboratory-scale constructed wetland. Water Res 39:4643-4650. doi: 10.1016/j.watres.2005.09.017

Wu S, Kuschk P, Wiessner A, et al (2013) Sulphur transformations in constructed wetlands for wastewater treatment: A review. Ecol Eng 52:278-289. doi: 10.1016/j.ecoleng.2012.11.003

Yoda M, Miyaji Y, Kitagawa M (1987) Long Term Competition Between Sulfate Reducing and Methane Producing Bacteria for Acetate in Anaerobic Biofilm. Water Res 21:1547-1556.

Yuan Z, Li J, Cui L, et al (2013) Interaction of silver nanoparticles with pure nitrifying bacteria. Chemosphere 90:1404-1411. doi: 10.1016/j.chemosphere.2012.08.032

Zhang D, Hua T, Xiao F, et al (2015) Phytotoxicity and bioaccumulation of ZnO nanoparticles in Schoenoplectus tabernaemontani. Chemosphere 120:211-219. doi: 10.1016/j.chemosphere.2014.06.041

Zhang D, Hua T, Xiao F, et al (2014) Uptake and accumulation of CuO nanoparticles and CdS/ZnS quantum dot nanoparticles by Schoenoplectus tabernaemontani in hydroponic mesocosms. Ecol Eng 70:114-123. doi: 10.1016/j.ecoleng.2014.04.018

Zhang W (2014) Nanoparticle aggregation: Principles and modelling. In: Capco DG, Chen Y (eds) Nanomaterial, Advances in Experimental Medicine and Biology. Springer Science+Business Media, Doordrecht, pp 19-43

Zhang W, Yao Y, Li K, et al (2011) Influence of dissolved oxygen on aggregation kinetics of citratecoated silver nanoparticles. Environ Pollut 159:3757-3762. doi: 10.1016/j.envpol.2011.07.013

Zhang Y, Chen Y, Westerhoff P, Crittenden J (2009) Impact of natural organic matter and divalent cations on the stability of aqueous nanoparticles. Water Res 43:4249-4257. doi: 10.1016/j.watres.2009.06.005

Zhou D, Keller A a. (2010) Role of morphology in the aggregation kinetics of $\mathrm{ZnO}$ nanoparticles. Water Res 44:2948-2956. doi: 10.1016/j.watres.2010.02.025 
799 Zhu Z-J, Wang H, Yan B, et al (2012) Effect of surface charge on the uptake and distribution of gold 800 nanoparticles in four plant species. Environ Sci Technol 46:12391-8. doi: 10.1021/es301977w 801 